\title{
Application Research on Stabilizing Treatment of Dredged Sediment
}

\author{
Shi Yannan ${ }^{1}$, Zhang Chaojie ${ }^{1,2,3}$, Yu Jiongqi ${ }^{1,2,3}$, Tang Mingli ${ }^{1}$ \\ ${ }^{1}$ Zhejiang Guang Chuan Engineering Consulting Co., LTD, Hangzhou 310020, China; \\ ${ }^{2}$ Zhejiang Institute of Hydraulics \& Estuary, Hangzhou 310020, China; \\ ${ }^{3}$ Zhejiang Provincial Key Laboratory of Hydraulic Disaster Prevention and Mitigation, Hangzhou 310020, China.
}

\begin{abstract}
In order to improve water quality, to ensure the capacity of normal flood discharge and river transport, it carried out a lot of dredging work across the country recently. For harmful sediment's second pollution and recycling use, this study selected five kinds of sediment. And point A was determined as the research object by using the geo-accumulation index to evaluate the heavy metal. Then the sediment was mixed with lime, fly ash, kaolin clay, sodium silicate, sodium carbonate and polyvinyl alcohol as mud stabilizing materials. Experimental research shows that, copper loss of stabilized soil's toxicity leaching agent reaches more than $95 \%$, and the permeability coefficient was $10-5 \mathrm{~cm} / \mathrm{s}$ orders of magnitude. In this paper, it ensures GW7 as the best choice of plants experiments, which are $5 \%$ fly ash, $1 \%$ lime, $3 \%$ kaolin clay, $3 \%$ sodium silicate, $3 \%$ sodium carbonate and $1 \%$ polyvinyl alcohol, through the ways of permeability, water retention, SEM and XRD. The scheme effectively stabilizes copper, and keeps the plants as better form than others. But it has different effect on different plants. Thus it should consider planting varieties optimization in actual applications.
\end{abstract}

\section{Introduction}

With the deepening of Zhejiang Province "five water treatment", it appeared a lot of dredged sediment in a short time. Because dredged sediment had high moisture content and large volume, it needed a large amount of land for stacking. In addition, a big part of dredged sediment is polluted by different degree, especially the urban river sediment, it contains a lot of organic matter, nitrogen and phosphorus nutrition, and some harmful heavy metals, pathogenic bacteria, virus microorganism, and toxic organic compounds, and so on. It make the mud easy to blacken and rot ${ }^{[1]}$. If untreated direct stacking, it would cause secondary pollution, especially in cultivated land. Therefore, the dredging sediment's stabilization and harmlessness disposal has become one of the problems to be solved urgently.

Stabilization refers to the transformation of harmful substances into substances with low solubility, low toxicity and low mobility, that reduces the pollution potential of waste materials ${ }^{[2]}$. Stable technology is generally implemented by curing, that the curing materials change the soil mechanics properties, and reduce pollutants dissolved out ${ }^{[3]}$. The techniques mainly include cement, thermoplastic materials, hot and hard materials, lime, large encapsulation, self-cementing, and glass solidification, etc. ${ }^{[4-5]}$.

According to the literature, lime, cement, fly ash can improve the soil $\mathrm{pH}$, and reduce the microorganism and organic matter content in the sediment, while steady heavy metals form of cadmium and chromium. Because microbial decomposition and metabolism constantly changes sediment chemical conditions, it will affect the form of heavy metals ${ }^{[6]}$. Kaolin is basically neutral and has fine pores on the surface, which offers good adsorption and desorption properties to nitrogen, phosphorus, potassium and organic carbon ${ }^{[7]}$. And Iron powder, sodium carbonate and sodium silicate can stabilize copper ${ }^{[8]}$.

In 2016, Zhejiang Province had dredged more than 100 million cubic meters sediment. At present, its utilization mode was simplex, that mainly was backfilled. In this, the use of agricultural fields is accounted for $22 \%$, and backfill is at $33 \%$, contained low-lying areas, mines and reclamation areas backfill. And landscaping is at $7 \%$. But agricultural fields and landscaping are affected by mud properties. Additionally, the search for land is increasingly difficult as the backfill area decreases. Although the concept of "dredging sediment is an available resource" has been gradually recognized, it is necessary to carry out systematic research to translate this understanding into practice $\mathrm{e}^{[9]}$.

Based on the problems of dredged sediment's high water content, diversified pollution, and it has difficulty in storage yard, this paper put forward to use mud as planting soil through solidifying single pollution factor silt, which will provide more resource utilization possibility for polluted sediment.

\footnotetext{
* Corresponding author: syn.0419@163.com
} 


\section{Screening of Sediment}

\subsection{Evaluation Standard of Geo-accumulation Index Method}

The geo-accumulation index (Igeo) is a quantitative index of heavy metal pollution in water environment. Because it not only considers the man-made pollution factors, environmental geochemical background values, etc., but also in consideration of the dynamics of background value by the natural rock forming effect. Therefore, the application is widely distributed ${ }^{[10]}$. Evaluation standard of geo-accumulation index is shown in table 1.

Table 1. Evaluation Criterion of Geo-accumulation Index and Pollution Series

\begin{tabular}{|c|c|c|}
\hline Level & Igeo & Degree of Contamination \\
\hline 0 & $(-\infty, 0)$ & No \\
\hline 1 & $(0,1]$ & Mild \\
\hline 2 & $(1,2]$ & Less Moderate \\
\hline 3 & $(2,3]$ & Moderate \\
\hline 4 & $(3,4]$ & Less Heavy \\
\hline 5 & $(4,5]$ & Heavy \\
\hline 6 & $(5,+\infty)$ & Serious \\
\hline
\end{tabular}

\subsection{The Calculation Formula of Geo- accumulation Index}

Computational formula of geo-accumulation index is shown in formula (1). The background value of heavy metals in soil of Zhejiang Province [13] is shown in table 2.

$$
\mathrm{I}_{\text {geo }}=\log _{2}\left[C_{n} /\left(K * B_{n}\right)\right]
$$

Where $\mathrm{Cn}$ is the content of heavy metal $\mathrm{n}$ in sediment, $\mathrm{Bn}$ is the background value of heavy metals in soil of Zhejiang Province, $\mathrm{K}$ is correction factor, and usually $\mathrm{K}$ is 1.5 .

Table 2. Soil element background values of heavy metals in Zhejiang Province

\begin{tabular}{|c|c|}
\hline heavy metal & $\begin{array}{c}\text { background } \\
\text { values }\end{array}$ \\
\hline $\mathrm{Cu}$ & 22.63 \\
\hline $\mathrm{Zn}$ & 83.06 \\
\hline $\mathrm{Pb}$ & 23 \\
\hline $\mathrm{Cd}$ & 0.17 \\
\hline $\mathrm{Ni}$ & 23.93 \\
\hline $\mathrm{Hg}$ & 0.17 \\
\hline $\mathrm{As}$ & 6.88 \\
\hline
\end{tabular}

\subsection{The Evaluation Results of Geo-accumulation Index}

This study screened five different sediments as research object. The results of Igeo were shown in table 3 . The results showed that the Igeo of $\mathrm{Cu}$ in sample A was less heavy pollution, and the factor was relatively simple. Therefore, the test chose sample A, and its physical properties were shown in table 4 .

Table 3. Geo-accumulation index(Igeo) calculation of heavy metal in sediment

\begin{tabular}{|c|c|c|c|c|c|c|c|}
\hline $\begin{array}{c}\text { The } \\
\text { sample } \\
\text { of } \\
\text { Sedime } \\
\text { nt }\end{array}$ & $\begin{array}{l}\text { Igeo }_{\mathrm{geo}} \\
\mathrm{Cu}\end{array}$ & $\begin{array}{c}\text { Igeo } \\
\text { Zn }\end{array}$ & $\begin{array}{c}\text { Igeo }_{\text {geo }} \\
\mathrm{Pb}\end{array}$ & $\begin{array}{l}\text { Igeo }_{\text {Cd }} \\
\text { Cd }\end{array}$ & $\begin{array}{c}\text { Igeo }_{\text {gi }} \\
\mathrm{Ni}\end{array}$ & $\begin{array}{c}\text { Igeo }_{\text {ge }} \\
\mathrm{Hg}\end{array}$ & $\begin{array}{l}\text { Igeo } \\
\text { As }\end{array}$ \\
\hline \multirow[b]{2}{*}{ A } & 3.15 & 0.74 & 1.59 & 0.08 & 0.33 & 0.61 & 0.83 \\
\hline & $\begin{array}{c}\text { Less } \\
\text { Hea } \\
\text { vy }\end{array}$ & Mild & $\begin{array}{l}\text { Less } \\
\text { Mod } \\
\text { erate }\end{array}$ & Mild & Mild & Mild & Mild \\
\hline \multirow[b]{2}{*}{ B } & 1.7 & 0.97 & 1.15 & 1.85 & 0.51 & 0.25 & 0.5 \\
\hline & $\begin{array}{l}\text { Less } \\
\text { Mod } \\
\text { erate }\end{array}$ & Mild & $\begin{array}{l}\text { Less } \\
\text { Mod } \\
\text { erate }\end{array}$ & $\begin{array}{l}\text { Less } \\
\text { Mod } \\
\text { erate }\end{array}$ & Mild & Mild & Mild \\
\hline \multirow[t]{2}{*}{ C } & $\begin{array}{c}- \\
0.63\end{array}$ & $0 . \overline{22}$ & 0.06 & $\begin{array}{c}- \\
1.67\end{array}$ & $\begin{array}{c}- \\
1.58 \\
\end{array}$ & $\begin{array}{c}- \\
0.41\end{array}$ & 0.29 \\
\hline & No & No & No & No & No & No & Mild \\
\hline \multirow{2}{*}{ D } & $\begin{array}{c}- \\
0.56\end{array}$ & $\begin{array}{c}- \\
0.02 \\
\end{array}$ & $\begin{array}{c}- \\
0.06 \\
\end{array}$ & $\begin{array}{c}- \\
0.28 \\
\end{array}$ & 0.03 & $\begin{array}{c}- \\
1.21\end{array}$ & $\begin{array}{c}- \\
0.27\end{array}$ \\
\hline & No & No & No & No & Mild & No & No \\
\hline \multirow[t]{2}{*}{$\mathrm{E}$} & 0.34 & 0.25 & $\begin{array}{c}- \\
0.56\end{array}$ & $\begin{array}{c}- \\
0.21\end{array}$ & $\begin{array}{c}- \\
0.92\end{array}$ & $\begin{array}{c}- \\
2.21\end{array}$ & 0.05 \\
\hline & Mild & Mild & No & No & No & No & Mild \\
\hline
\end{tabular}

Table 4. The statistical table of point A sediment's physical property

\begin{tabular}{|c|c|}
\hline The sample of Sediment & A \\
\hline moisture content $(\%)$ & 51.8 \\
\hline wet density $\left(\mathrm{g} / \mathrm{cm}^{3}\right)$ & 1.67 \\
\hline dry density $\left(\mathrm{g} / \mathrm{cm}^{3}\right)$ & 1.1 \\
\hline void ratio $(\%)$ & 1.486 \\
\hline liquid limit $(\%)$ & 54.6 \\
\hline plastic limit $(\%)$ & 31.2 \\
\hline the specific gravity of solids & 2.74 \\
\hline coefficient of vertical permeability $(\mathrm{cm} / \mathrm{s})$ & $4.4 \times 10^{-7}$ \\
\hline
\end{tabular}

\section{3 the Stabilization Experimental Scheme on Sediment}

Firstly, it took $5 \%$ fly ash $+1 \%$ lime $+3 \%$ kaolin as the main curing agent, because the Igeo of $\mathrm{Cu}$ in sample $\mathrm{A}$ was less heavy pollution. The mixing amount of curing agent was in percentage of dried mud quality. And the specific solutions were determined by the adjustment of $\mathrm{pH}$. They were shown in table 5. In this experiment, it studied the reduction rate of copper concentration, water retention and permeability.

Table 5. Curing ratio test scheme

\begin{tabular}{|c|c|c|c|c|c|c|}
\hline \multirow{2}{*}{$\begin{array}{l}\text { Sam } \\
\text { ple } \\
\text { num } \\
\text { ber }\end{array}$} & \multicolumn{5}{|c|}{ the mixing amount of curing agent $/ \%$} & \multirow{2}{*}{$\mathrm{pH}$} \\
\hline & $\mathrm{Na}_{2} \mathrm{SiO}_{3}$ & $\mathrm{Na}_{2} \mathrm{CO}_{3}$ & $\mathrm{MgSO}_{4}$ & $\mathrm{Fe}_{2}\left(\mathrm{SO}_{4}\right)_{3}$ & PVA & \\
\hline $\begin{array}{c}\mathrm{GW} \\
0\end{array}$ & 1 & l & 1 & / & 1 & 6.9 \\
\hline
\end{tabular}




\begin{tabular}{|c|c|c|c|c|c|c|}
\hline \multirow{2}{*}{$\begin{array}{l}\text { Sam } \\
\text { ple } \\
\text { num } \\
\text { ber }\end{array}$} & \multicolumn{4}{|c|}{ the mixing amount of curing agent $/ \%$} & \multirow{2}{*}{ pH } \\
\cline { 1 - 6 } $\begin{array}{c}\mathrm{GW} \\
6\end{array}$ & 3 & $/$ & $/$ & 3 & 1 & 7.3 \\
\hline $\begin{array}{c}\mathrm{GW} \\
7\end{array}$ & $/$ & 3 & $/$ & 3 & 1 & 8.6 \\
\hline $\begin{array}{c}\mathrm{GW} \\
8\end{array}$ & 1 & 1 & 1 & 3 & 1 & 6.2 \\
\hline $\begin{array}{c}\mathrm{GW} \\
9\end{array}$ & $/$ & $/$ & 3 & 3 & 1 & 5.4 \\
\hline $\begin{array}{c}\mathrm{GW} \\
10\end{array}$ & $/$ & $/$ & 6 & $/$ & 1 & 7.9 \\
\hline
\end{tabular}

\section{Results Analysis}

\subsection{Heavy Metal Leaching Test}

Heavy metals are mostly stabilized in the form of metal hydrates and metal hydroxides in solidified bodies ${ }^{[3]}$. Heavy metal morphology are change by $\mathrm{pH}$ of soil. Thus, it affects the bio-availability of heavy metals ${ }^{[11]}$. On the condition of acidic, $\mathrm{H}^{+}$can destroy the hydration products and obstruct the settlement of metal compounds, or reduce calcium hydroxide concentration reacted with $\mathrm{OH}^{-}$, which promoting the dissolution of hydration products and accelerating the leaching of heavy metals [12].

The test took acetic acid solution $(\mathrm{pH}=4.93+0.05)$ as leach liquor. It simulated acid condition, then study all kinds of solidified sediment's stability. Refer to "soil environmental quality standard" (GB15618-1995), it tested eight heavy metals' content and leaching concentration of copper, zinc, nickel, lead, cadmium, chromium, mercury and arsenic. As shown in table 6, according to "surface water environment quality standard" (GB 3838-2002), leaching liquid of original sample GW0's copper, lead and cadmium were beyond standard of the class V water quality. Solidified sediments of GW6-GW10's toxic leaching results were much better, and they meet standard of the class I $\sim$ III water quality.

Table 6. The heavy metals table of solidified sediment leachate

\begin{tabular}{|l|c|c|c|c|c|c|}
\hline Testing items & GW0 & GW6 & GW7 & GW8 & GW9 & GW10 \\
\hline $\mathrm{Cu}(\mathrm{mg} / \mathrm{L})$ & 4.29 & 0.02 & $\mathrm{ND}$ & 0.12 & 0.18 & 0 \\
\hline $\mathrm{Zn}(\mathrm{mg} / \mathrm{L})$ & 0.55 & 0.42 & 0.39 & 0.38 & 0.21 & 0.45 \\
\hline $\mathrm{Ni}(\mathrm{mg} / \mathrm{L})$ & 0.23 & 0.17 & 0.06 & 0.27 & 0.28 & 0.14 \\
\hline $\mathrm{Pb}(\mathrm{mg} / \mathrm{L})$ & 0.15 & $\mathrm{ND}$ & $\mathrm{ND}$ & $\mathrm{ND}$ & $7.7 \times 10^{-3}$ & $\mathrm{ND}$ \\
\hline $\mathrm{Cd}(\mathrm{mg} / \mathrm{L})$ & $2.0 \times 10^{-2}$ & $5.5 \times 10^{-4}$ & $\mathrm{ND}$ & $1.5 \times 10^{-3}$ & $3.0 \times 10^{-3}$ & $4.5 \times 10^{-4}$ \\
\hline $\mathrm{Cr}(\mathrm{mg} / \mathrm{L})$ & 0.03 & $\mathrm{ND}$ & $\mathrm{ND}$ & 0.04 & 0.05 & 0.04 \\
\hline $\mathrm{Hg}(\mathrm{mg} / \mathrm{L})$ & $8.0 \times 10^{-4}$ & $\mathrm{ND}$ & $\mathrm{ND}$ & $\mathrm{ND}$ & $6.0 \times 10^{-5}$ & $5.0 \times 10^{-5}$ \\
\hline $\mathrm{As}(\mathrm{mg} / \mathrm{L})$ & $1.0 \times 10^{-3}$ & $\mathrm{ND}$ & $\mathrm{ND}$ & $4 \times 10^{-4}$ & $1.0 \times 10^{-4}$ & $\mathrm{ND}$ \\
\hline $\begin{array}{l}\text { surface water } \\
\text { environment } \\
\text { quality standard }\end{array}$ & $\begin{array}{l}\text { Beyond } \\
\text { class V }\end{array}$ & $\mathrm{I} \sim \mathrm{III}$ & $\mathrm{I} \sim \mathrm{III}$ & $\mathrm{I} \sim \mathrm{III}$ & $\mathrm{I} \sim \mathrm{III}$ & $\mathrm{I} \sim \mathrm{III}$ \\
\hline
\end{tabular}

Copper leaching reduced rate before planting $\left(\alpha_{n}\right)$ and copper leaching changed rate before and after planting $\left(\Delta \mathrm{x}_{\mathrm{n}}\right)$ were calculated by formula (2) and (3).

$$
\begin{gathered}
\alpha_{n}=\frac{\rho_{0}-\rho_{n}}{\rho_{0}} \\
\Delta x_{n}=\frac{\rho_{n}-\rho_{n}^{\prime}}{\rho_{n}^{\prime}}
\end{gathered}
$$

Where $\rho_{0}$ is original sample's copper leaching concentration before planting $(\mathrm{mg} / \mathrm{L}), \rho_{\mathrm{n}}$ is solidified sediment of n's copper leaching concentration before planting $(\mathrm{mg} / \mathrm{L}), \rho_{\mathrm{n}}^{\prime}$ is solidified sediment of n's copper leaching concentration after planting $(\mathrm{mg} / \mathrm{L})$.

From figure 1, copper leaching reduced rate before planting reached more than $95 \%$. It proves that the group of $\mathrm{Na}_{2} \mathrm{SiO}_{3}, \mathrm{Na}_{2} \mathrm{CO}_{3}, \mathrm{MgSO}_{4}$ and $\mathrm{Fe}_{2}\left(\mathrm{SO}_{4}\right)_{3}$ can stable copper ions effectively.

As shown in the figure 2, solidified sediment GW7's copper leaching concentration was minimum after planting kale, and it was basically the same as before curing. This shows that GW7 is the most effective for curing copper, and there is no soluble free copper ion in solidified sediment.

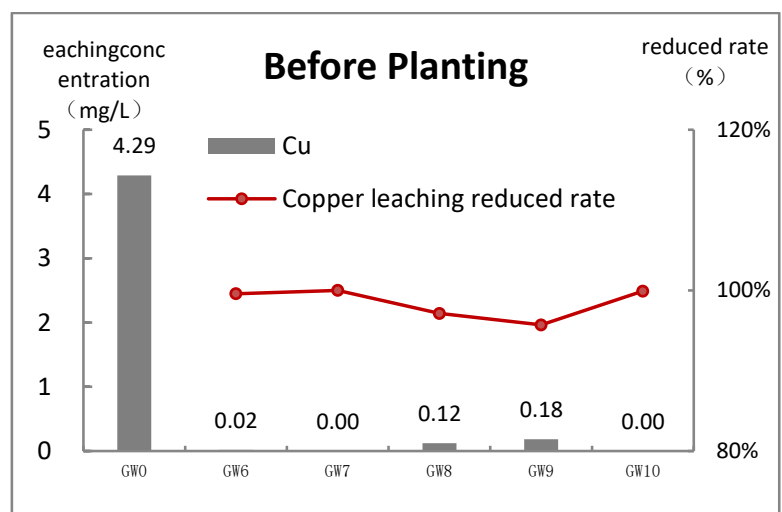

Fig. 1. The reduction rate of preplant stabilized soil's copper leaching

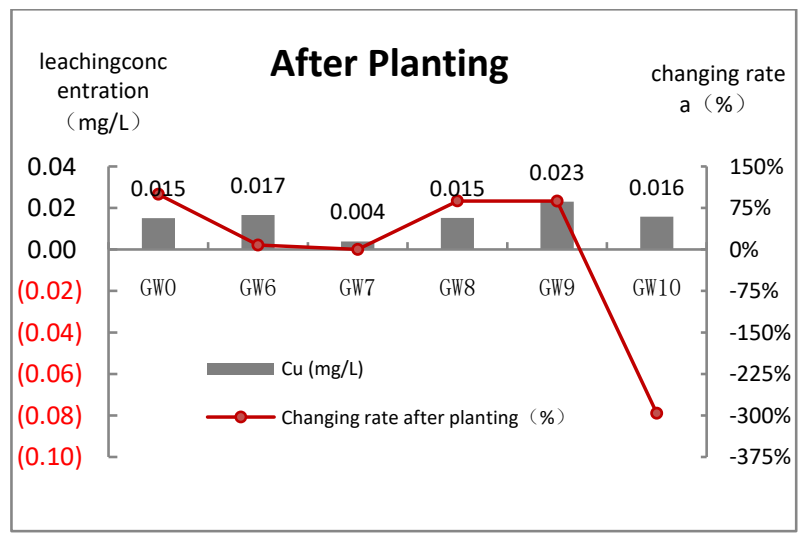

Fig. 2. The change rate of planting stabilized soil's copper leaching

\subsection{Percolation Test}

According to "Rules of Geotechnical Testing" [14], infiltration is the phenomenon of water moving in porous media. It tested the seepage rate of solidified sediments under $20 \mathrm{kPa}$ vacuum pressure in order to understand the influence of different dosage of curing stabilizer. 
As shown in the figure 3 , it used quantifiable multiunit vacuum suction-filter device by Independent $R \& D^{[15]}$. It recorded the relationship between the suction filter water and time at $20^{\circ} \mathrm{C}$, and drawed the relation curve of water filter and time, and measure the mud sample thickness, then got the permeability coefficient of each solidified soil. It was calculated by constant head penetration test formula.

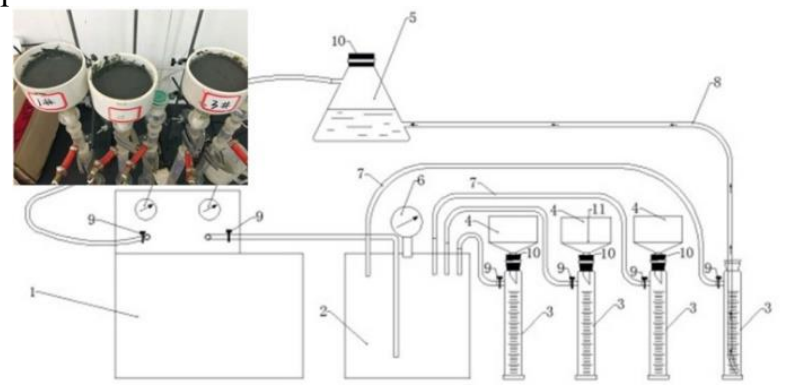

Fig. 3. The change rate of planting stabilized soil's copper leaching

From figure 4 and table 7, under the constant vacuum of $20 \mathrm{kPa}$, the osmotic coefficient of GW10 is $10^{-4} \mathrm{~cm} / \mathrm{s}$, and the rest is about $10^{-5} \mathrm{~cm} / \mathrm{s}$. The ranking of infiltration is $\mathrm{GW} 10>\mathrm{GW} 8>\mathrm{GW} 9>\mathrm{GW} 0>\mathrm{GW} 6>\mathrm{GW} 7$. At the same time, it shows that the seepage rate increases with time, because there is a lot of fiber in stabilized soil. It provides water seepage channels to improve late permeability.

Table 7. The table of solidified sediment permeability coefficient

\begin{tabular}{|c|c|c|c|}
\hline $\begin{array}{c}\text { vacuu } \\
\mathrm{m} \\
\text { degre } \\
\mathrm{e}\end{array}$ & $\begin{array}{c}\text { Sample } \\
\text { number }\end{array}$ & $\begin{array}{c}\text { water } \\
\text { penetration } \\
\text { rate } \\
\mathrm{mL} / \mathrm{s}\end{array}$ & $\begin{array}{c}\text { permeability } \\
\text { coefficient } \\
\mathrm{cm} / \mathrm{s}\end{array}$ \\
\hline \multirow{4}{*}{$20 \mathrm{kPa}$} & GW0 & 0.88 & $6.07 \times 10^{-5}$ \\
\cline { 2 - 4 } & GW6 & 0.73 & $5.01 \times 10^{-5}$ \\
\cline { 2 - 4 } & GW7 & 0.45 & $3.11 \times 10^{-5}$ \\
\cline { 2 - 4 } & GW8 & 1.24 & $8.59 \times 10^{-5}$ \\
\cline { 2 - 4 } & GW9 & 1.14 & $7.88 \times 10^{-5}$ \\
\cline { 2 - 4 } & GW10 & 8.57 & $5.92 \times 10^{-4}$ \\
\hline
\end{tabular}

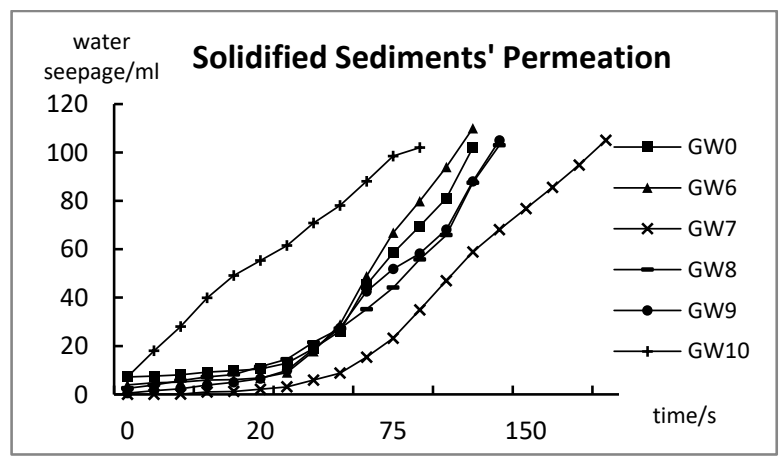

Fig. 4. The emission rate of GW0 and GW6-GW10 stabilized soil
It was helpful to research plant planting experiments through study soil water retention. Put the mud into beaker after stir well, add water to the saturation, and took out and put it in a funnel for 24 hours, then weigh the soil and calculate the initial water content. After that, weigh the soil every 24 hours, observed about 30 days, and calculated soil moisture content.

As shown in the figure 5, the ranking of water retention is $\mathrm{GW} 10<\mathrm{GW} 8<\mathrm{GW} 6<\mathrm{GW} 9<\mathrm{GW} 0<$ GW7. It is mainly consistent with the law of permeability.

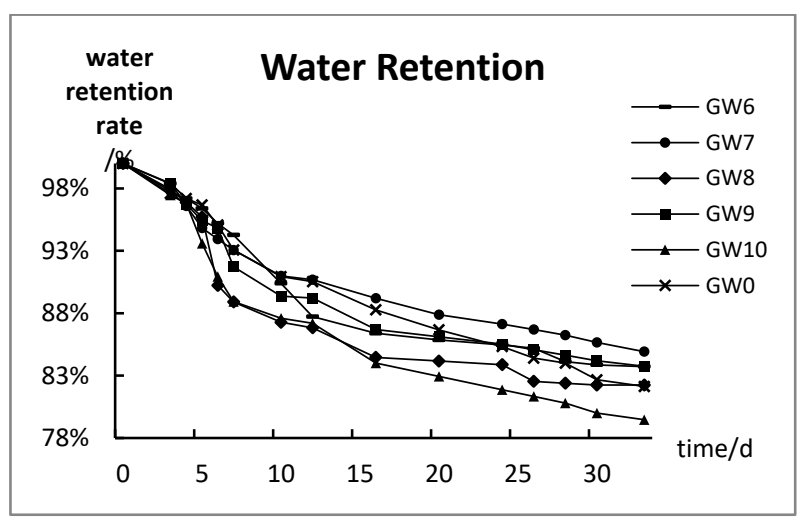

Fig. 5. The water-retention rate of GW0 and GW6-GW10 stabilized soil

\subsection{Microscopic Test}

From figure 6 and table 8, it had stronger peak and larger area near $26.72^{\circ}$. It proves that solidified sediments consists of quartz primarily. From figure 7 , there is a lot of fiber in GW7. It is ensured that plants can breathe normally by the pore and seepage diameter. Therefore, the cultivation of kale grows best in the solidified soil of GW7.

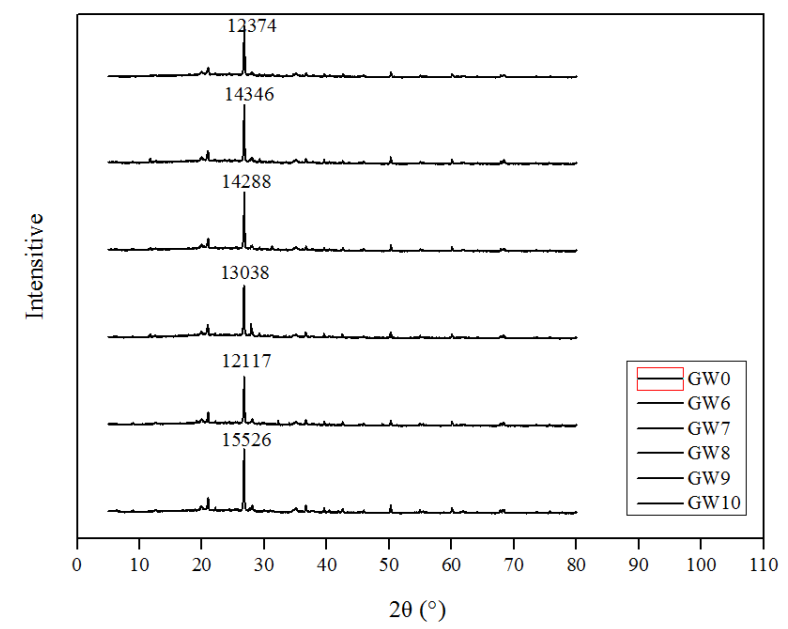

Fig. 6. XRD analysis of GW0 and GW6-GW10 stabilized soil

\subsection{Water Retention Test}




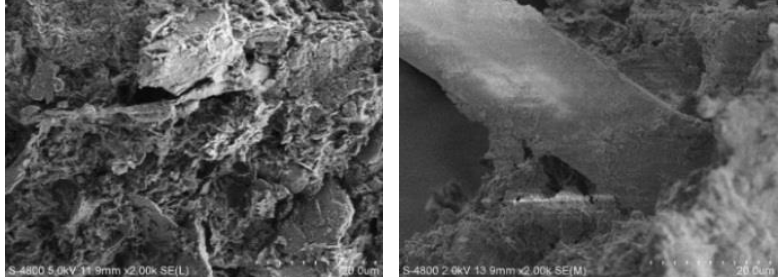

Fig. 7. GW0 and GW7 stabilized soil's SEM photos

Table 8. The eigenvalue of GW7 stabilized soil's XRD

\begin{tabular}{|c|c|c|c|}
\hline $\begin{array}{c}\text { Sample } \\
\text { number }\end{array}$ & $2 \theta\left({ }^{\circ}\right)$ & $\mathrm{d}(\AA)$ & Intensitive \\
\hline \multirow{3}{*}{ GW7 } & 20.92 & 4.24 & 3999 \\
\cline { 2 - 4 } & 26.72 & 3.33 & 13038 \\
\cline { 2 - 4 } & 27.86 & 3.20 & 4158 \\
\cline { 2 - 4 } & 50.22 & 1.81 & 2254 \\
\hline
\end{tabular}

\section{Conclusion}

This paper presents and research stabilizing treatment of dredged sediment. The result shows that copper loss of stabilized soil's toxicity leaching agent reaches more than $95 \%$, and the permeability coefficient was $10-5$ $\mathrm{cm} / \mathrm{s}$ orders of magnitude. And it ensures GW7 as the best choice of plants experiments, which are 5\% fly ash, $1 \%$ lime, 3\% kaolin clay, 3\% sodium silicate, 3\% sodium carbonate and $1 \%$ polyvinyl alcohol, through the ways of permeability, water retention, SEM and XRD. The scheme effectively stabilizes copper, and keeps the plants as better form than others. However, it has different effect on different plants. Thus it should consider planting varieties optimization in actual applications.

\section{Acknowledgements}

This work was financially supported by Zhejiang Province Science and Technology Agency Key Research and Development Project (2017C03008), Zhejiang Province Science and Technology Agency Research Institutes Special Project (2016F50003), Zhejiang Institute of Hydraulics \& Estuary Dean's Fund Project(ZIHE2016011),Zhejiang Province Science and Technology Agency Innovative Methods for Technical Projects (2016IM020100-4), Zhejiang Province Water Resources Department Science and Technology Planning Project(RB1614), Zhejiang Province Water Resources Department Science and Technology Planning Project(RC1733).

\section{References}

1. Jia Yunhui. Technology of Repair and treatment on Polluted river sediment[J]. Science \& Technology Information, 2014, (4): 226-227.
2. Wang Zhiyong. Analysis of solidification/stabilization on urban life sludge[J]. Urban and rural construction, 2012, (18): 55-58.

3. Malviya R, Chaudhary R. Leaching behavior and immobilization of heavy metals in solidified/stabilized products[J]. Journal of hazardous materials, 2006, 137(1): 207-217

4. Jiang Jianguo, Wang Wei. The history, present status and development of solidification/stabilization technology in treating with hazardous waste[J]. Advances in Environmental Science, 1998, 6(1): 5562.

5. Wang Wei, Yuan Guangjue. The state and development of solid waste disposal in China [J]. Environmental Science, 1997, 18(2): 87-90.

6. Ji Shunjian. Effects of solidification/stabilization of sludge on the morphology of heavy metal[D], Hohai University, 2008.

7. Liu Xiumei, Zhang Fudao, Zhang Shuqing, etc. Study on adsorption and desorption properties of nanokaoline to nitrogen, phosphorus, postash and organic carbom[J]. Scientia Agricultura Sinica, 2005, 38(1): 102-109.

8. Chen C L, LOSL, Kuan Wenhui, etal, Stabilization of $\mathrm{Cu}$ in Acid extracted Industrial Sludge Using a Microwave Process[J]. Journal of Hazardous Materials, 2005, 123(13): 256-261.

9. Fu Gui, Zhao Dezhao, Cheng Haifeng. Comparison and analysis of comprehensive utilization of dredged materials at home and abroad[J]. Port \& Waterway ngineering, 2011, 3(451): 90-96.

10. Li Gongzhen, Wang Xiao. Study on the pollution and release of heavy metals in the main canal of the Beijing-Hangzhou Grand Canal (Subei Section) [M]. Jiangsu Xuzhou: China University of Mining and Technology , 2013:55-58.

11. Ding Jianghua, Wen yanmao, Shu Qiang. Fraction transformation of cadmium and Zinc in soils[J]. Urban environment \& Urban ecology, 2001,14(2): 47-49.

12. Chen Q Y, Tyrer M, Hills C D, et al. Immobilization of heavy metal in cement-based solidification/stabilisation:A review[J]. Waste Management, 2009, 29(1): 390-403

13. Fan Yunhui, Wang Yanqing. Background characteristics of soil elements in four plants of Zhejiang Province[J]. Geophysical and Geochemical Exploration, 2009, (02):132-134.

14. SL 237-1999, Test methods of soils[S]. Beijing: Ministry of Water Resources of the People's Republic of China, 1999.

15. Shi Yannan, Zhang Chaojie, Yu Jiongqi, etc. A quantifiable multi-link vacuum extraction stabilizer[P]. China: ZL201620060109.2, 2016. 